\title{
CHANGES IN THE STATUS AND DISTRIBUTION OF THE CINEREOUS AND FULVOUS OWLS IN MEXICO
}

NATHAN PIEPLOW, 317 UCB, University of Colorado, Boulder, Colorado 80309; npieplow@gmail.com

ANDREW SPENCER, 562 Ellis Hollow Creek Rd., Ithaca, New York 14850

CARLOS SANCHEZ, 8305 SW 152nd Ave., Apt. 312, Miami, Florida 33193

MANUEL GROSSELET, Colina 145, Lomas de Bezares, Miguel Hidalgo, C.P. 11910, Ciudad de México, D.F., Mexico

ABSTRACT: Once widespread and apparently common in the mountains of mainland Mexico, to which it is endemic, the Cinereous Owl (Strix sartorii) seems to have declined precipitously. In 2015, 2016, 2017, and 2019 we searched for the Cinereous Owl in eight Mexican states where it had been reported previously. We detected it at only a single site, Rancho La Noria on Cerro San Juan, Nayarit. Our results suggest that the Cinereous Owl may have disappeared from much of its former range, and that the Fulvous Owl (Strix fulvescens) may now inhabit areas in Oaxaca formerly occupied by the Cinereous Owl, perhaps as a result of habitat alteration. The Cinereous Owl may qualify for recognition as vulnerable or endangered. Comprehensive surveys are urgently needed to establish its current status and distribution. Such surveys should also be used to determine the current distribution of the Fulvous $\mathrm{Owl}$, and to investigate the reasons why it now occurs in areas formerly occupied by the Cinereous Owl.

Specimens of the Cinereous Owl (Strix sartorii) have been taken in at least nine Mexican states, as far south as Oaxaca and as far north as Durango and San Luis Potosí (Figure 1). The known specimen locations are widely scattered throughout the Sierra Madre Occidental and the Sierra Madre Oriental, at elevations ranging from as low as 600 meters to as high as 3000 meters.

The habitat of the bird appears to be montane pine and pine-oak forests. Ridgway (Baird and Ridgway 1873) reported that the type specimen was taken in the "pine region" of Hacienda Mirador, Veracruz (Figure 1M). Cox (1895) reported seeing a Cinereous Owl "in the deep pine forests about halfway up Peak Orizaba," but being unable to collect it. Binford (1989) described the habitat at the Oaxaca specimen locations as "high elevation humid pine-oak forest." The habitat on Cerro San Juan in Nayarit (Figure 1B), one of only two locations where the species has been recorded since 2015, is relatively humid pine-oak forest at about 1650 meters.

During the late $19^{\text {th }}$ and early $20^{\text {th }}$ centuries, the Cinereous Owl was widespread and, in the judgment of Salvin and Godman (1879), "apparently not uncommon in western Mexico.” Steve N. G. Howell (pers. comm.) reported to us that Charles Sibley had once told him of hearing Cinereous Owls "frequently" in Nayarit and Jalisco during his field work on towhee hybridization in the late 1940s and early 1950s.

By the second half of the $20^{\text {th }}$ century, the Cinereous Owl had apparently declined precipitously. A 1983 specimen from Guerrero (Universidad Autónoma de México Museum of Zoology 3581) is the only one taken after 1950. Binford (1989) listed the species as "rare" in Oaxaca, unrecorded there except for three specimens taken in 1857 and 1894. As recently as 2015, no 


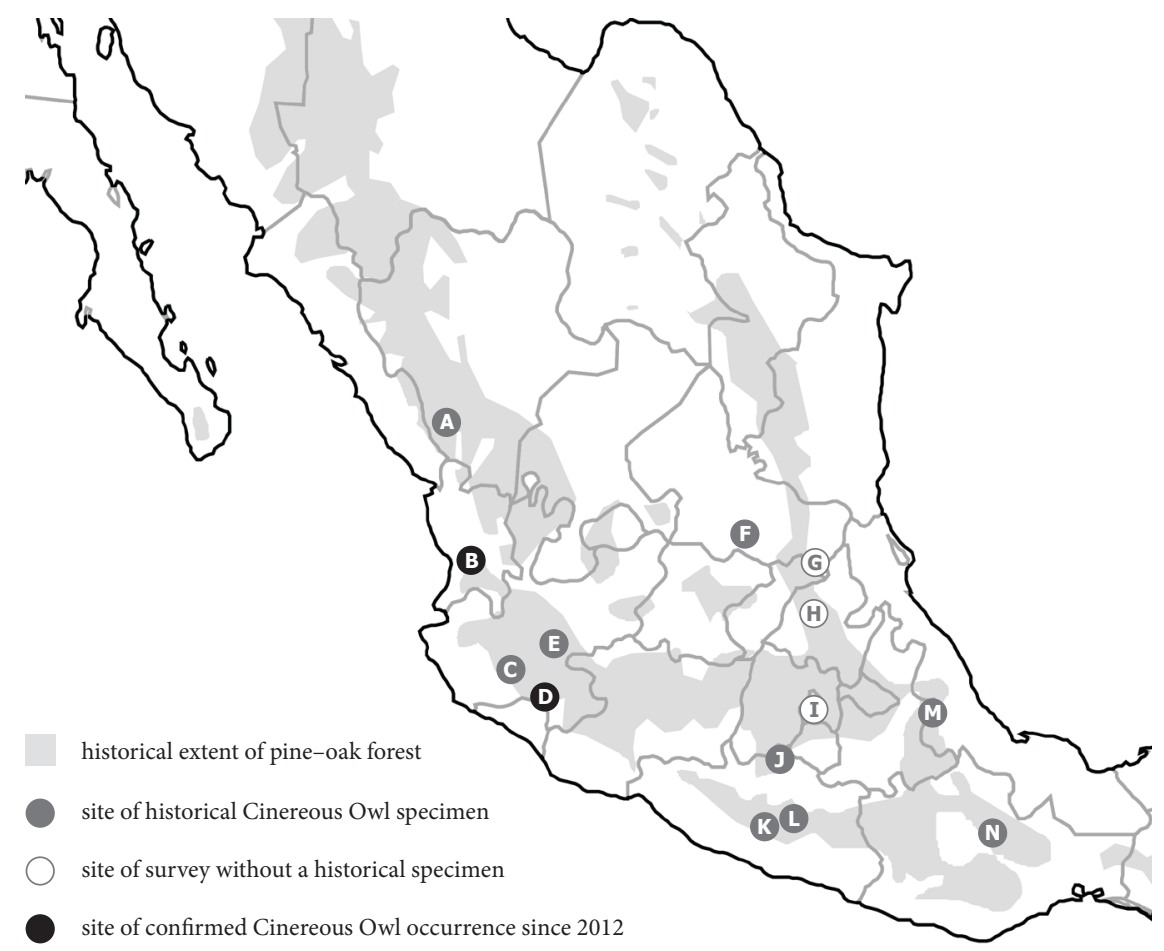

FIgURE 1. Locations of specimens of and surveys for the Cinereous and Fulvous Owls. A, La Ciudad, Durango; B, Cerro San Juan, Nayarit; C, Autlán, Jalisco; D, Parque Nacional Nevado de Colima, Jalisco; E, Cerro Viejo, Jalisco; F, Cerro Lucero, San Luis Potosí; G, La Trinidad, San Luis Potosí; H, Tlanchinol, Hidalgo; I, Parque Nacional Desierto de Leones, Ciudad de México; J, Coapango, Guerrero; K, Cerro Tiotepec, Guerrero; L, Parque Ecológico Estatal Omiltemi, Guerrero; M, Hacienda Mirador, Veracruz; N. Cerro San Felipe, Oaxaca.

photographs of sartorii had been published, and its voice remained undescribed. Strix sartorii has usually been considered a subspecies of S. varia, the Barred Owl, as by the American Ornithologists' Union (1998). Pieplow and Spencer (2020) summarized the evidence that it should be considered a separate species.

\section{METHODS}

In 2016, 2017, and 2019, we searched extensively for the Cinereous Owl throughout its historic range in Mexico. We prioritized areas with historical specimen records.

We know of 35 specimens of the Cinereous Owl collected at 19 named sites. Using specimen metadata, published sources, and maps, we established the locations of nine of these sites with a high degree of certainty (within 
roughly $5 \mathrm{~km}$ ). We located an additional seven sites with a moderate degree of uncertainty $(5-50 \mathrm{~km})$. But three of the 19 locations are uncertain. Two are specific only to state (Michoacán and Guerrero). The third specimen (Natural History Museum of the United Kingdom 1888.7.20.225) is labeled as "Ciudad Durango." This locality is often assumed to refer to the city of Durango, which sits in the open desert of the Mexican Plateau, far from the nearest habitat for the Cinereous Owl. However, we consider it more likely that this specimen is from the town known as "La Ciudad" in the state of Durango (Figure 1A), which lies at $23.73^{\circ} \mathrm{N}, 105.69^{\circ} \mathrm{W}$, about $110 \mathrm{~km}$ west-southwest of the city of Durango, and is surrounded by pine forest.

The 17 historical sites that can be located with at least moderate certainty cluster into 9 geographic areas, each consisting of sites within the same mountain range and likely within the same block of historically continuous habitat. The cluster of records in Nayarit since 2015 constitutes an additional area.

In June 2016, January 2017, and March 2019, we carried out informal surveys for the Cinereous Owl in six of the nine historically inhabited areas. The remaining three areas we did not visit because of security concerns. We also surveyed a few additional areas where we considered it possible that the species might occur.

All surveys were along roads and consisted of listening for a few minutes, then playing recordings of the rhythmic song and the series song of a Cinereous Owl recorded in Nayarit, then listening for a few more minutes. Surveys in Oaxaca also included broadcast of rhythmic song of the Fulvous Owl (Strix fulvescens). See Pieplow and Spencer (2020) for spectrograms and discussion of these calls.

We did not standardize the number of minutes spent listening, the number or order of songs broadcast, or the distance between survey points. On average, trials lasted about 10 minutes. Surveys consisted of 2-12 trials at points at least 250 meters apart. Surveys either began 30 minutes after sunset or concluded 30 minutes before sunrise. In 2016 we conducted approximately 41 trials across 9 sites, in 2017 we conducted 48 trials across 6 sites, and in 2019 we conducted 23 trials across 4 sites.

\section{RESULTS}

Our surveys in 2016, 2017, and 2019 did not detect any Cinereous Owls.

In the area of Tlanchinol, Hidalgo (Figure $1 \mathrm{H}$ ), we surveyed along the Huazalingo road on the evening of 3 June 2016 and on the Lontla track on the morning of 4 June 2016. The habitat at both sites was good-quality cloud forest with little, if any, pine. We surveyed at La Trinidad, San Luis Potosí (Figure 1G), on the evening of 4 June 2016 and the morning and evening of 5 June 2016. The habitat here was good-quality cloud forest grading into humid pine-oak forest. We had no particular expectation of finding Cinereous Owls in cloud forest, a habitat from which they are unreported, but as this habitat is (or once was) widespread in areas between locations of specimens in the Sierra Madre Oriental, we considered it possible that it might support the species locally.

On the evening of 6 June and the morning of 7 June 2016, we surveyed Cerro Lucero, San Luis Potosí (Figure 1F). We believe that our survey included 
the exact location where Robert J. Newman collected two Cinereous Owls in 1950. The area is privately owned, and we obtained permission for our surveys from the inhabitants of the nearby farmhouse. Although the canopy of the pine-oak forest remained nearly continuous in places, logging had removed all pines of large diameter, and grazing had removed nearly all understory.

On the evening of 9 June and the morning of 10 June 2016, we surveyed the lower elevations of the Parque Nacional Nevado de Colima in Jalisco (Figure 1D), from the park boundary to the start of the zone of oyamel fir (Abies religiosa). This stretch of road passes through high-quality pine-oak forest with many tall and robust pines.

On the morning of 17 June 2016, broadcasting songs of both species, we surveyed for the Cinereous and Fulvous Owls at km 119 and km 148 along Highway 175 between Oaxaca and Tuxtepec in the state of Oaxaca (Figure $1 \mathrm{~N})$, in areas of fairly tall, dry pine-oak forest that had been grazed fairly clean of understory. We detected three Fulvous Owls at km $119\left(17.52^{\circ} \mathrm{N}\right.$, $96.51^{\circ} \mathrm{W}$ ), including a pair that responded vigorously to playback, permitting good recordings and photographs (https://ebird.org/checklist/S30307453).

On the morning of 18 June 2016, we surveyed the rather sparse pine-oak forest below the settlement of Benito Juárez, above Teotitlán del Valle, Oaxaca. On the morning of 19 June 2016, we surveyed the Villa Alta road just outside Totontepec, Oaxaca. This area contained good-quality cloud forest with only a few pines. We detected one Fulvous Owl. On the morning of 20 June 2016, we surveyed Cerro San Felipe in Oaxaca. This area contains good-quality pine-oak forest, including some tall and massive pines. We detected one Fulvous Owl.

On the evening of 6 January and the morning of 7 January 2017 we returned to survey the Parque Nacional Nevado de Colima in Jalisco. On the evening of 7 January we surveyed the lower portions of the Volcán de Fuego road that heads west from Mexico Highway 54D just south of Atenquique, Jalisco. Road conditions and the closure of the upper portion of the route by volcano activity prevented us from reaching an elevation with many pine trees.

On the morning of 8 January 2017 we surveyed the lower portions of the Radio Microondas Víboras road on the northwest flank of Nevado de Colima, Jalisco. The area contained good-quality pine-oak forest, including tall and large-diameter pines. On the evening of 8 January 2017 we surveyed the Puerto Los Mazos microwave tower road above Autlán, Jalisco (Figure 1C). The area was too low and dry to support many pine trees.

On the evening of 9 January 2017 we surveyed Cerro Viejo, $22 \mathrm{~km}$ southwest of Guadalajara, Jalisco (Figure 1E). The area is owned by the Ejido San Miguel Cuyutlán, and we obtained permission to enter for our surveys. (An ejido is a communal land grant awarded to farmers by the Mexican government.) The forest had been extensively logged; the remaining trees were almost exclusively oaks.

On the morning of 11 January 2017 we surveyed the Parque Nacional Desierto de Leones in Mexico City (Figure 1I). The area included some pine-oak forest with tall pines.

On the evening of 26 March 2019 we surveyed along the road to La Pintada, off Mexico Highway 196 above El Paraíso, Guerrero. The habitat was cloud forest with only a few pines. On the morning and evening of $27 \mathrm{March}$ 2019, we surveyed along Mexico Highway 196 from about $5 \mathrm{~km}$ below Puerto 
El Gallo to about $5 \mathrm{~km}$ above it, on the south flank of Cerro Tiotepec, to within about $5 \mathrm{~km}$ of the peak (Figure $1 \mathrm{~K}$ ). Local residents advised us not to continue farther up the road at night because of security concerns. The area contained good quality pine-oak forest, including some tall and massive pines. The area of the peak itself, which we visited only in daylight, contained good-quality coniferous forest with a large number of oyamel firs.

On the evening of 29 March 2019 we surveyed the area above Azinyahualco, Guerrero (Figure 1L), on land owned by the local Ejido Azinyahualco, with permission. The area was steep and rocky, covered primarily by low brush, with only a few scattered pine trees. We did not survey at the nearby location of Omiltemi on the advice of local residents who cited security concerns. However, J. L. Mena (pers. comm.) visited the Omiltemi area in daylight in 2013. He reported that the site has been severely degraded by logging, with large areas being completely cleared for the raising of livestock and cultivation of the opium poppy, and that pine trees remain in only a few isolated stands.

\section{DISCUSSION}

\section{Apparent Range Expansion by the Fulvous Owl}

The Fulvous Owl occurs from Honduras to southern Mexico; its habitat is montane pine forest and cloud forest (e.g., Dickey and van Rossem 1938, Gómez de Silva et al. 1999). Prior to 2009, most researchers considered the Cinereous and Fulvous Owls allopatric, their ranges separated by the low-lying Isthmus of Tehuantepec. For many years, the only evidence of the Fulvous Owl northwest of the isthmus consisted of four specimens supposedly taken at Totontepec, Oaxaca, in 1942 by Mario del Toro Avilés. These specimens (now in the Moore Laboratory of Zoology, Occidental College, Los Angeles) have long been controversial, in part because no other evidence was available to support an extension of the Fulvous Owl's range across the isthmus. Several authors (e.g., Binford 1989) cited examples of apparently incorrect locations on labels of other specimens collected by del Toro Avilés to cast doubt on his Totontepec Fulvous Owl specimens.

Since 2009, however, multiple photographs and audio recordings have conclusively established the occurrence of the Fulvous Owl at several locations in the Sierra Madre de Oaxaca north of Oaxaca City (Ramírez-Julián et al. 2011, eBird.org, xeno-canto.org). These locations include Cerro San Felipe (Figure 1N), which includes or sits adjacent to the locations of the $19^{\text {th }}$ century specimens of the Cinereous Owl.

In 2016 we recorded a Fulvous Owl at Totontepec (ML 171293391), the site of del Toro Avilés' controversial specimens. All the other specimens that del Toro Avilés labeled "Totontepec" are of species expected at that location (J. Maley pers. comm.). Thus we believe it likely that del Toro Avilés' Fulvous Owl specimens were indeed procured at that site, implying that Fulvous Owls have occurred in Oaxaca at least since 1942.

Meanwhile, the Cinereous Owl remains unrecorded in Oaxaca since 1894. It appears that the Fulvous Owl is now occupying areas in Oaxaca where the Cinereous Owl used to occur. The reasons for the apparent change in distribution of both species remain unknown. 


\section{Status of the Cinereous Owl}

Our failure to detect the Cinereous Owl during our 2016, 2017, and 2019 surveys suggests that the species, once widespread and "not uncommon," is now rare and local, and may qualify for designation as vulnerable or endangered. Since 2015, the species continues to be detected regularly in the vicinity of Cerro San Juan, Nayarit (Figure 1B). However, we and other observers have failed to document it in recent decades at most sites in its historical range.

A comprehensive survey effort is urgently required to establish the extent and the causes of the Cinereous Owl's decline. Surveys are also needed to determine the extent and causes of the apparent expansion of the Fulvous Owl into areas formerly occupied by the Cinereous Owl. It is possible that habitat alteration such as the selective logging of the largest pine trees has proved detrimental to the Cinereous Owl and beneficial to the smaller Fulvous Owl, perhaps by reducing the average size of available nest sites.

If the Cinereous and Fulvous Owls are in contact anywhere, it is possible that they interbreed or compete in those areas, as the Barred and Spotted Owls do in the northwestern United States (Gutiérrez et al. 2007). However, given the smaller size of the Fulvous Owl, it seems unlikely that it would displace its larger congener via direct competition (R. Gutiérrez pers. comm.). It is possible that the disappearance of the Cinereous Owl from Oaxaca has removed interspecific competition that might previously have prevented Fulvous Owls from occupying the area. If this is the case, the range expansion of the Fulvous Owl may actually provide additional evidence of decline of the Cinereous Owl (R. Gutiérrez pers. comm.).

Future surveyors should consider whether the relatively short duration of the listening periods in our surveys may have reduced the likelihood of our detecting a Cinereous Owl. Barred Owls (McGarigal and Fraser 1985) and Cinereous Owls (M. Stackhouse pers. comm.) frequently approach in response to broadcast of their songs silently, vocalizing only after many minutes, if at all. Broadcast of the Cinereous Owl's series song in preference over its rhythmic song might increase the likelihood of detection and reduce response time (M. Stackhouse pers. comm.). An optimal survey protocol might set points farther apart (up to $1 \mathrm{~km}$ ) but increase the number of points surveyed per transect and the number of transects completed per night (R. Gutiérrez pers. comm.).

It is also possible that the maximum elevation of our surveys was too low. After completing our surveys, we were able to view Fernando Romo's photographs from 6 October 2012 of a Cinereous Owl on Nevado de Colima, Jalisco (Figure 1D), at an altitude of 3800 meters, well above the transition into oyamel fir forest, and above the highest altitude of our surveys. This record suggests that Cinereous Owls should also be sought at higher elevations in forest of oyamel fir.

\section{ACKNOWLEDGMENTS}

We thank Alberto Martínez, José Luis Mena, and Bob McGuire for accompanying us on surveys in the field. Steve N. G. Howell was instrumental in our successful 2015 effort to document the Cinereous Owl in Nayarit. We also thank Ned Brinkley, 
Leonardo Chapa Vargas, Víctor L. Güitrón, Gerardo Hernández Vázquez, Dan Lane, Roberto Pedraza Ruiz, Michael Retter, Fernando Romo, Chris Sharpe, Mark Stackhouse, Ingrid Tello-López, and Bernardillo Villa Bonilla for helpful discussion about Strix owls and nocturnal survey sites in Mexico.

For access to museum specimens and other key information, we thank Carla Cicero, Florine Pascale, and Lelena Avila at the Museum of Vertebrate Zoology at the University of California, Berkeley; Paul R. Sweet and Lydia Garetano of the American Museum of Natural History; Van Remsen, Steve Cardiff, and Tammie Jackson at the Louisiana State University Museum of Natural Science; Mark Adams at the Natural History Museum in London; and James Maley and Jessie Salter at the Moore Laboratory of Zoology at Occidental College.

We thank George Barrowclough and R. J. Gutiérrez for their technical review of our manuscript.

\section{LITERATURE CITED}

American Ornithologists' Union. 1998. Check-list of North American Birds, $7^{\text {th }}$ ed. Am. Ornithol. Union, Washington, DC.

Baird, S. F., and Ridgway, R. 1873. On some new forms of American birds. Bull. Essex Inst. 5(12): 197-201.

Binford, L. C. 1989. A distributional survey of the birds of the Mexican state of Oaxaca. Ornithol. Monogr. 43; doi.org/10.2307/40167673.

Cox, U. O. 1895. A collection of birds from Mount Orizaba, Mexico. Auk 12:357; doi.org/10.2307/4068943.

Dickey, D. R., and van Rossem, A. J. 1938. The birds of El Salvador. Field Mus. Nat. Hist. Zool. Ser 23.

Gómez de Silva G., H., González-García, F., and Casillas-Trejo, M. P. 1999. Birds of the upper cloud forest of El Triunfo, Chiapas, Mexico. Ornitol. Neotrop. $10: 1-26$.

Gutiérrez, R. J., Cody, M., Courtney, S., and Franklin, A. B. 2007. The invasion of Barred Owls and its potential effect on the Spotted Owl: A conservation conundrum. Biol. Invasions 9:181-196; doi.org/10.1007/s10530-006-9025-5.

McGarigal, K., and Fraser, J. D. 1985. Barred Owl responses to recorded vocalizations. Condor 87:552-553; doi.org/10.2307/1367961.

Pieplow, N., and Spencer, A. 2020. Vocal differences among the Barred, Cinereous, and Fulvous Owls. W. Birds 51:122-128; doi.org/21199/WB51.2.5.

Ramírez-Julián, R., González-García, F., and Reyes-Macedo, G. 2011. Registro del búho leonado Strix fulvescens en el estado de Oaxaca, México. Rev. Mex. Biodivers. 82:727-730; doi.org/10.22201/ib.20078706e.2011.2.491.

Salvin, O., and Godman, R. D. 1879. Biologia Centrali-Americana. Aves, vol. III, part I. R. H. Porter, London. 